\title{
The development status of electric (BEV) and hydrogen (FCEV) passenger cars park in the world and new research possibilities of these cars in real traffic conditions
}

\begin{abstract}
Major markets across the European Union (EU) are concentrated on rapid development of electromobility. This policy is demonstrated - among others - by recent sales of electric cars: within the past 3 quarters of $2018-24.7$ thousand electric cars have been registered in Germany, 20.3 thousand in France, 15.3 thousand in the Netherlands and 31.4 thousand in Norway. Unfortunately, only 867 EVs have been registered in Hungary, 469 in the Czech Republic, 468 in Romania, 411 in Poland and 348 in Slovenia.

Unit energy consumption of electric cars was often defined in NEDC cycle. In real conditions of road traffic, it may differ from values recorded in a drive cycle. The article presents results of a study on energy consumption of electric cars in Poland along RDE (Real Driving Emissions) testing route in terms of vehicle energy consumption per drive unit ( $\mathrm{km}, 100 \mathrm{~km})$. The use of fuel cells in cars may bring a change in the type of used vehicles in the long run. Both globally and in the EU wide-ranging actions are undertaken to implement fuel cell technology. Also, the infrastructure of hydrogen filling stations is developed. At present the most rapidly developing country in this area is Japan. The article addresses the issue of energy consumption per drive unit by cars equipped with fuel cells as both type of vehicles, i.e. EV and FCV use electric motors. The article also discusses infrastructure development in the EU and Poland, charging and fuelling of the said vehicles, respectively.
\end{abstract}

Key words: energy, electric cars, RDE, consumption, fuel cell

\section{Introduction}

Since September 1st of this year certification of new type (Euro 6) passenger cars and light trucks in the EU includes the exhaust emissions testing of these vehicles, i.e. the Real Driving Emissions (RDE) procedure [1-7, 18, 19].

Road test specifications cannot be optional. The route must include a drive-in urban area, rural and on a highway. Duration of the trip must be between 90 and 120 minutes. Setting the route for an RDE drive for the purpose of exhaust emission testing from light vehicles requires the fulfilment of numerous requirements, including those relating to ambient temperature, topographic height of the test, driving style (dynamic specifications of the trip), trip's duration, length of specific sections of the test (urban, rural, highway) etc. Setting such route for the purpose of research work by the author of this article was the primary challenge facilitating future certification testing related to the assessment of noxious substances in the exhaust emitted by light vehicles, but also in the development work relating to, for example, the estimation of energy consumption by electric and hybrid vehicles or those equipped with fuel cells in light of the development of electromobility and hydrogenization of vehicle transport.

\section{Development of electromobility - battery electric vehicles (BEVs)}

In 2010 there had been just 16 thousand BEVs registered worldwide (Table 1), of which 6 thousand were registered that year (Table 2). The registration of newly purchased electric passenger cars began to grow rapidly from that moment to come to 39 thousand in 2011, 58 thousand in 2012, 112 thousand in 2013, 191 thousand in 2014, 325 thousand in 2015, 466 thousand in 2016 and 759 thousand in 2017 [8, 9].

The increased sales had been generated mostly by China with a production of more than $60 \%$ of BEVs manufactured globally. The world fleet of such vehicles was respectively 16 thousand vehicles in 2010, 55 thousand in 2011, 113 thousand in 2012, 227 thousand in 2013, 420 thousand in 2014, 740 thousand in 2015 and over 1.2 million in 2016, of which 255 thousand in Europe (including approx. 160 thousand vehicles in the EU).

The largest fleet of BEV passenger cars was noted in China (over 480 thousand vehicles), the US (almost 300 thousand vehicles), Japan (86 thousand vehicles), Norway (100 thousand vehicles), France (67 thousand vehicles) and Germany (approx. 41 thousand vehicles). Poland with its fleet of several hundred BEVs has been outpaced significantly by countries such as Italy or Portugal (in 2018 about 1,3 thousand vehicles) [10].

Despite an over 70-fold increase of the world fleet of BEVs in years 2016-2017 electric passenger cars still account for just $0.1 \%$ of the total number of passenger cars registered in the world.

Table 1. Newly registered electric passenger cars (BEV) in years 2010-2017, in thousands [8]

\begin{tabular}{|l|c|c|c|c|c|c|c|c|}
\hline Description & 2010 & 2011 & 2012 & 2013 & 2014 & 2015 & 2016 & 2017 \\
\hline Poland & - & 0 & 0 & 0 & 0.1 & 0.2 & 0.1 & 0.4 \\
\hline EU28 & 0.5 & 7.9 & 12.4 & 22.1 & 35.2 & 54.2 & 63.5 & 97.5 \\
\hline Norway & 0.4 & 1.8 & 4.2 & 8.2 & 18.1 & 27.8 & 29.5 & 44.9 \\
\hline Switzerland & - & - & 1.0 & 1.0 & 1.0 & 3.3 & 3.3 & 4.8 \\
\hline Europe & 0.9 & 9.9 & 17.4 & 31.0 & 54.2 & 85.3 & 96.3 & 147.2 \\
\hline Canada & - & 0,2 & 0,6 & 1,6 & 2,8 & 4,4 & 5,2 & 14,9 \\
\hline China & 1.0 & 4.7 & 9.6 & 14.6 & 48.9 & 146.7 & 257.0 & 468.0 \\
\hline Japan & 2.4 & 12.6 & 13.5 & 14.8 & 16.1 & 10.5 & 15.5 & 24.5 \\
\hline USA & 1.2 & 9.7 & 14.6 & 47.7 & 63.4 & 71.0 & 86.7 & 104.5 \\
\hline In total & 6.4 & 38.5 & 57.8 & 112.1 & 190.8 & 325.4 & 466.4 & 759.1 \\
\hline
\end{tabular}

Electric vehicles (plug-in and battery electric) comprised $1.48 \%$ of all new car registrations in EU-28 in 2017 [11]. There is a significant variation across the EU countries for example, in Sweden electric vehicle registrations 
are $5.5 \%$ of all new cars [11]. Outside of the EU, Norway is a clear leader with $39.2 \%$ of new car registration being electric vehicles $[12,13]$.

Table 2. Registered fleet of passenger BEVs in years 2010-2016, in thousands [8]

\begin{tabular}{|l|c|c|c|c|c|c|c|}
\hline Description & 2010 & 2011 & 2012 & 2013 & 2014 & 2015 & 2016 \\
\hline EU28 & 1.9 & 9.3 & 21.2 & 44.3 & 74.2 & 121.8 & 161.3 \\
\hline Norway & 3.3 & 5.3 & 9.5 & 19.7 & 41.8 & 72.0 & 98.9 \\
\hline Europe & 2.7 & 12.1 & 28.1 & 59.0 & 107.0 & 182.4 & 251.4 \\
\hline Canada & 0 & 0.2 & 0.9 & 2.5 & 5.3 & 9.7 & 14.9 \\
\hline China & 1.5 & 6.3 & 15.9 & 30.6 & 79.5 & 226.2 & 483.2 \\
\hline India & 0,9 & 1,3 & 2,8 & 2,9 & 3,3 & 4,3 & 4,8 \\
\hline Japan & 3.5 & 16.1 & 29.6 & 44.3 & 60.5 & 70.9 & 86.4 \\
\hline $\begin{array}{l}\text { South } \\
\text { Korea }\end{array}$ & 0 & 0.3 & 0.8 & 1.4 & 2.8 & 5.7 & 10.8 \\
\hline USA & 3.8 & 13.5 & 28.2 & 75.9 & 139.3 & 210.3 & 297.0 \\
\hline In total & 16.4 & 55.1 & 112.9 & 226.8 & 420.3 & 745.6 & 1208.9 \\
\hline
\end{tabular}

In [9] is suggested that by 2030 battery electric vehicles sales could be between $13 \%$ and $21 \%$ of total new car sales in climate goal and regulation scenarios. Including range extended electric vehicles increase is $34 \%$ and $51 \%$. According to one of the scenarios aims to achieve is 10 $\mathrm{g} \mathrm{CO}_{2}$-eqv/km [9].

If Europe were to move to a zero - emission car fleet the share of new car sales which would have to be zero emission (battery electric and fuel cell) would need to be around $20 \%$ in $2030,40 \%$ in 2040 and $50 \%$ under a medium forecast [9].

In terms of total vehicles, there could be around 24 million electric cars on the road in Europe in 2030, around $10 \%$ of Europe's car fleet. This is based on there being 18 million new cars sold in Europe [14] and assuming a 7\% market share of new cars in 2020 , a $17 \%$ market share in 2030 and linear growth between the years [13].

The majority of life cycle analyses suggest that well-towell (WTW) GHG emissions per km driven of BEVs in Europe lower than ICEVs and hybrid vehicles. Based on the carbon-intensity of the EU electricity mix in 2015, the WTW emissions of a mid-sized BEV were between 60 and $76 \mathrm{~g} \mathrm{CO}_{2}$ eqv $/ \mathrm{km}$. This is between $47 \%$ and $58 \%$ lower than the emissions of an average mid-sized ICEV passenger car in 2015, at $143 \mathrm{~g} \mathrm{CO}_{2}$ eqv/ $/ \mathrm{km} \mathrm{[13].}$

The growth of electromobility observed at present is forcing a number of research efforts with respect to electric vehicles. The main ones here are the determination of their range, the power of engines implemented on these vehicles, battery durability or the test of energy use by these vehicles. The latter issue is discussed in this article, which presents examples of the measurements of energy consumption by passenger cars on a route set for the purpose of RDE tests.

\section{RDE test and testing energy consumption by an electric passenger car}

The trip sequence includes driving in an urban area and then in a rural area and on a highway. The trip component in urban area, rural area and on the highway is conducted in a continuous manner. The use in rural area may be interrupted by brief periods of use in urban areas if these are located along the route path. The use on a highway may be interrupted by brief periods of use in urban or rural areas, for example while driving through toll collection booths or along sections where road construction work is being conducted. If, for practical reasons, another test sequence is justifiable, the sequence of use in urban area, rural area and on a highway may be changed upon permission of the body issuing the certification [15].

The use in urban area is characterized by vehicle speeds not exceeding $60 \mathrm{~km}$ per hour, in an rural area vehicle speed ranges from $60 \mathrm{~km}$ per hour to $90 \mathrm{~km}$ per hour and on a highway above $90 \mathrm{~km}$ per hour (Table 3). The trip included approximately $34 \%$ use in an urban area, 33\% in rural area and $33 \%$ on a highway. The term 'approximately' means a range of \pm 10 percentage points from the above percentage values. However, the use in urban area must account for at least $29 \%$ of the total route driven. Vehicle speed will usually not exceed $145 \mathrm{~km}$ per hour. The maximum speed may be exceeded by $15 \mathrm{~km}$ per hour for no more than $3 \%$ of the duration of highway component. Local speed restrictions remain in force during PEMS test regardless of other legal consequences. Exceeding local speed restrictions as such does not nullify the results of PEMS test. Average driving speed (including stop periods) in the urban area should be between $15 \mathrm{~km}$ per hour and $30 \mathrm{~km}$ per hour. Stop periods, defined as time when vehicle's speed is less than $1 \mathrm{~km}$ per hour, should account for at least $10 \%$ of the time of use in the urban area. Use in urban area includes several stop periods lasting at least 10 seconds. Avoid situations where a single excessively long stop period would account for over $80 \%$ of the total stop period during the use in an urban area. Driving speed on a highway includes range of $90 \mathrm{~km}$ per hour to at least $110 \mathrm{~km}$ per hour. Vehicle speed must exceed $100 \mathrm{~km}$ per hour for at least 5 minutes.

Table 3. Requirements for the drive [15]

\begin{tabular}{|l|c|c|c|c|}
\hline Requirements & Unit & Urban & Rural & Highway \\
\hline Speed & $\mathrm{km} / \mathrm{h}$ & $0-60$ & $60-90$ & $90-130$ \\
\hline Distance & $\%$ & $\begin{array}{c}\sim 34 \\
( \pm 10 \%)\end{array}$ & $\begin{array}{c}\sim 33 \\
( \pm 10 \%)\end{array}$ & $\begin{array}{c}\sim 33 \\
( \pm 10 \%)\end{array}$ \\
\hline $\begin{array}{l}\text { Minimum } \\
\text { distance }\end{array}$ & $\mathrm{km}$ & 16 & 16 & 16 \\
\hline $\begin{array}{l}\text { Share of trip } \\
\text { component }\end{array}$ & $\%$ & $>29$ & - & - \\
\hline
\end{tabular}

Trip duration must range from 90 to 120 minutes. The difference between the starting and end point of the trip may not exceed 100 meters in altitude above the sea level. Minimum distance during the use in urban area, rural and on the highway must reach at last $16 \mathrm{~km}$ (detailed requirements are listed in Table 4) [15].

In the RDE studies, a A passenger car was used (Fig. 1).

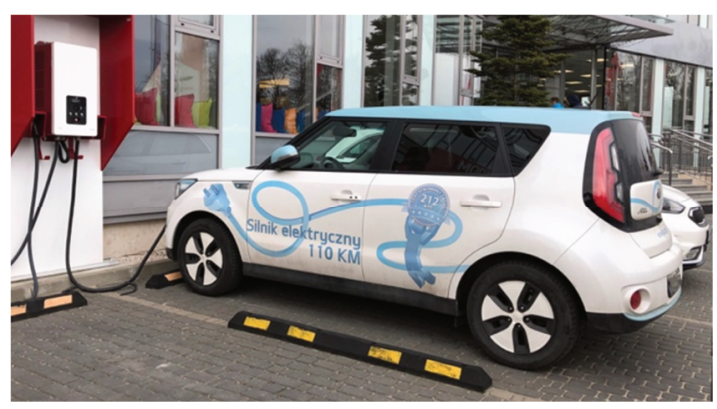

Fig. 1. Electric passenger car tested 
Table 4. Detailed requirements for RDE tests [15]

\begin{tabular}{|c|c|}
\hline Specification & Requirements \\
\hline \multirow{3}{*}{$\begin{array}{l}\text { Ambient temperature } \\
\left(\mathrm{T}_{\mathrm{z}}\right)\end{array}$} & - normal range: $0^{\circ} \mathrm{C} \leq \mathrm{T}_{\mathrm{z}}<30^{\circ} \mathrm{C}$ \\
\hline & - lower extended range: $-7^{\circ} \mathrm{C} \leq \mathrm{T}_{\mathrm{z}}<0^{\circ} \mathrm{C}$ \\
\hline & - upper extended range: $30^{\circ} \mathrm{C}<\mathrm{T}_{\mathrm{z}} \leq 35^{\circ} \mathrm{C}$ \\
\hline \multirow{2}{*}{$\begin{array}{l}\text { Topographic test } \\
\text { height }(\mathrm{h})\end{array}$} & - normal: $\mathrm{h} \leq 700 \mathrm{~m}$ n.p.m. \\
\hline & - extended: $700<\mathrm{h} \leq 1300 \mathrm{~m}$ n.p.m. \\
\hline \multirow{3}{*}{$\begin{array}{l}\text { Assessment of the } \\
\text { impact of ambient } \\
\text { weather and road } \\
\text { specification and } \\
\text { driving style }\end{array}$} & $\begin{array}{l}\text { - cumulative altitude gain: below } 1200 \mathrm{~m} / \\
100 \mathrm{~km}\end{array}$ \\
\hline & $\begin{array}{l}\text { - relative positive acceleration (RPA): } \\
\text { greater than } \mathrm{RPA}_{\min } \text { (for all types of driving } \\
\text { conditions) }\end{array}$ \\
\hline & $\begin{array}{l}\text { - a product of acceleration and speed } \\
\left(\mathrm{v} \cdot \mathrm{a}_{\text {pos }}\right) \text { : less than } \mathrm{v} \cdot \mathrm{a}_{\text {pos min }} \text { (for all types of } \\
\text { driving conditions) }\end{array}$ \\
\hline \multirow[t]{2}{*}{$\begin{array}{l}\text { Thermal state of the } \\
\text { vehicle prior to test }\end{array}$} & $\begin{array}{l}\text { - cold start of the vehicle: coolant below } \\
70^{\circ} \mathrm{C} \text {, } \\
\text { - duration of at least } 300 \mathrm{~s} \\
\end{array}$ \\
\hline & $\begin{array}{l}\text { - emission from cold start not included in } \\
\text { RDE test }\end{array}$ \\
\hline $\begin{array}{l}\text { Duration of } \\
\text { individual stop }\end{array}$ & - not to exceed $180 \mathrm{~s}$ \\
\hline $\begin{array}{l}\text { Use of exhaust } \\
\text { purification systems }\end{array}$ & $\begin{array}{l}\text { - one-time regeneration of solid particle filter } \\
\text { may cause a repeat of the RDE test; two } \\
\text { regenerations are taken into consideration in } \\
\text { RDE fume exhaust test results }\end{array}$ \\
\hline $\begin{array}{l}\text { Use of driving } \\
\text { comfort systems }\end{array}$ & $\begin{array}{l}\text { - normal usage as intended (e.g. use of air } \\
\text { conditioning system) }\end{array}$ \\
\hline Vehicle load & $\begin{array}{l}\text { - vehicle weight: driver (and the passenger) } \\
\text { plus test equipment; maximum load at } \\
<90 \% \text { of the total of passenger weight and } \\
\text { vehicle payload }\end{array}$ \\
\hline Test requirements & - duration $90-120 \mathrm{~min}$ \\
\hline \multirow{5}{*}{$\begin{array}{l}\text { Requirements for } \\
\text { urban test } \\
\text { component }\end{array}$} & $-29-44 \%$ of the entire test length \\
\hline & - distance: more than $16 \mathrm{~km}$ \\
\hline & - vehicle speed (v): v $\leq 60 \mathrm{~km} / \mathrm{h}$ \\
\hline & - average speed: $15-40 \mathrm{~km} / \mathrm{h}$ \\
\hline & $\begin{array}{l}\text { - duration of stops: } 6-30 \% \text { of the urban com- } \\
\text { ponent }\end{array}$ \\
\hline \multirow{3}{*}{$\begin{array}{l}\text { Requirements for } \\
\text { rural test component }\end{array}$} & $-23-43 \%$ of the entire test length \\
\hline & - distance: more than $16 \mathrm{~km}$ \\
\hline & - vehicle speed $(\mathrm{v}): 60 \mathrm{~km} / \mathrm{h}<\mathrm{v} \leq 90 \mathrm{~km} / \mathrm{h}$ \\
\hline \multirow{5}{*}{$\begin{array}{l}\text { Requirements for } \\
\text { highway test } \\
\text { component }\end{array}$} & $-23-43 \%$ of the entire test length \\
\hline & - distance: more than $16 \mathrm{~km}$ \\
\hline & - vehicle speed (v): v > $90 \mathrm{~km} / \mathrm{h}$ \\
\hline & $\begin{array}{l}\text { - vehicle speed in excess of } 100 \mathrm{~km} / \mathrm{h} \text { for at } \\
\text { least } 5 \text { minutes }\end{array}$ \\
\hline & $\begin{array}{l}\text { - vehicle speed in excess of } 145 \mathrm{~km} / \mathrm{h} \text { for } \\
\text { a maximum of } 3 \% \text { of the trip }\end{array}$ \\
\hline
\end{tabular}

Designated trip route was shown on Fig. 2. It consists of urban, rural and highway components.

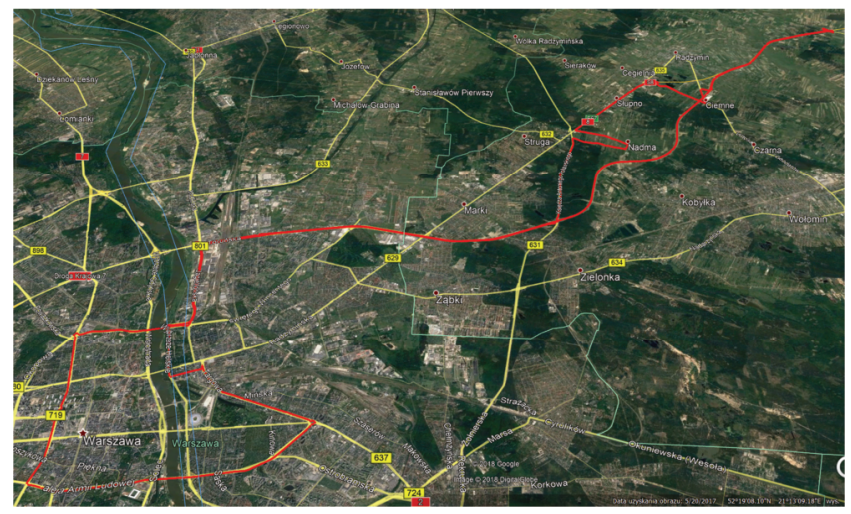

Fig. 2. Course of the designated RDE route
The speed of the car over time is shown on Fig. 3.

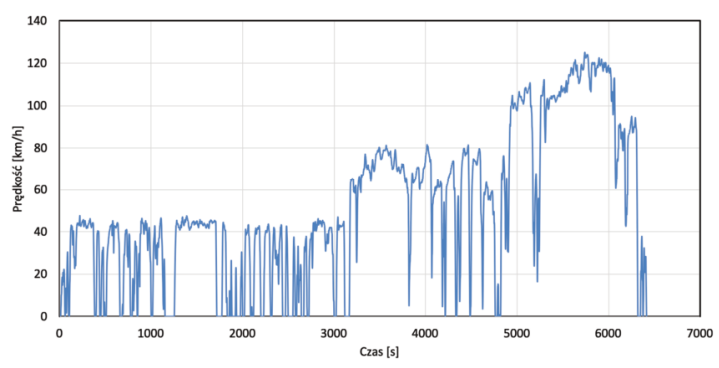

Fig. 3. The speed of the car over time

Energy consumption on this c. $92 \mathrm{~km}$ route was tested using Yokogawa 1806E power analyser (which allows the measurement of energy consumption and energy recovery, battery charging efficiency, etc.) and Semtech DS with GPS device (measuring the length of the distance travelled).

Tested electric passenger car had the following basic criteria:

- Overall length $\mathrm{x}$ width $\mathrm{x}$ height [mm]: $4140 \mathrm{x} 1800 \mathrm{x}$ 1593 ;

- Wheel base [mm]: 2570;

- Curb weight [kg]: (excluding a drivers with $75 \mathrm{~kg}$ ) 1510 ;

- Gross weight [kg]: 1800;

- Electric motor (type: Permanent Magnet AC Synchronous Motor), Voltage [V]: $360 \mathrm{~V}$, Max. power [kW/rpm]: 81.4/2730-8000, Max. torque [Nm/rpm]: 285/0-2730;

- Gear reduction unit: final gear ratio (constant): 8.206;

- OBC (On Board Charger): Max. power [kW] 6.6;

- High-Voltage Battery pack: Type: LIPB (Lithium Ion Polymer Battery), Voltage [V]: 360, Capacity [Ah]: 75, Energy [kWh]: 27, Power [kW]: 90, Weight [kg]: 277;

- 12V Battery: Capacity [Ah]: 45.

Test found to be carried out correctly (Table 5). For example:

Table 5. Confirmation the test has been carried out correctly

\begin{tabular}{|l|c|c|c|}
\hline \multicolumn{4}{|c|}{ Test correctness } \\
\hline \multicolumn{1}{|c|}{ Test specification } & Result & Requirement & Correctness \\
\hline Urban component [km] & 30.0 & $>16$ & Correct \\
\hline Rural component [km] & 28.6 & $>16$ & Correct \\
\hline Highway component [km] & 33.3 & $>16$ & Correct \\
\hline Total route length [km] & 91.9 & $>48$ & Correct \\
\hline Urban component [\%] & 32.7 & $29-44$ & Correct \\
\hline Rural component [\%] & 31.1 & $33 \pm 10$ & Correct \\
\hline Highway component [\%] & 36.2 & $33 \pm 10$ & Correct \\
\hline $\begin{array}{l}\text { Average speed on urban } \\
\text { route [km/h] }\end{array}$ & 27.8 & $15-40$ & Correct \\
\hline $\begin{array}{l}\text { Duration of stops on urban } \\
\text { route [\%] }\end{array}$ & 20.8 & $6-30$ & Correct \\
\hline $\begin{array}{l}\text { Trip duration at more than } \\
100 \mathrm{~km} / \mathrm{h}[\mathrm{min}]\end{array}$ & 15.8 & $>5$ & Correct \\
\hline Maximum speed [km/h] & 125.1 & $<160$ & Correct \\
\hline $\begin{array}{l}\text { Trip duration at more than } \\
\text { 145 km/h during the high- } \\
\text { way component [\%] }\end{array}$ & 0.0 & $<3$ & Correct \\
\hline Trip duration [min] & 106.9 & $90-120$ & Correct \\
\hline
\end{tabular}


Table 5cont.

\begin{tabular}{|c|c|c|c|}
\hline \multicolumn{4}{|c|}{ Cold start $(t=300 s)$} \\
\hline Coolant temperature $\left[{ }^{\circ} \mathrm{C}\right]$ & 0,0 & $<70$ & Correct \\
\hline $\begin{array}{l}\text { Maximum vehicle speed } \\
{[\mathrm{km} / \mathrm{h}]}\end{array}$ & 47.7 & $<60$ & Correct \\
\hline $\begin{array}{l}\text { Duration of vehicle stops } \\
\text { [s] }\end{array}$ & 20 & $<90$ & Correct \\
\hline In neutral after ignition [s] & 0 & $<15$ & Correct \\
\hline \multicolumn{4}{|c|}{ RPA } \\
\hline $\begin{array}{l}\text { Urban: data set no. } a_{i}>0,1 \\
\mathrm{~m} / \mathrm{s}^{2}\end{array}$ & 964 & $>150$ & Correct \\
\hline $\begin{array}{l}\text { Rural: data set no. } a_{i}>0,1 \\
\mathrm{~m} / \mathrm{s}^{2}\end{array}$ & 274 & $>150$ & Correct \\
\hline $\begin{array}{l}\text { Highway: data set no. } a_{i}> \\
0,1 \mathrm{~m} / \mathrm{s}^{3}\end{array}$ & 205 & $>150$ & Correct \\
\hline $\begin{array}{l}\text { Urban: average speed } \\
{[\mathrm{km} / \mathrm{h}]}\end{array}$ & 28.1 & & \\
\hline $\begin{array}{l}\text { Rural: average speed } \\
{[\mathrm{km} / \mathrm{h}]}\end{array}$ & 72.1 & & \\
\hline $\begin{array}{l}\text { Highway: average speed } \\
{[\mathrm{km} / \mathrm{h}]}\end{array}$ & 109.2 & & \\
\hline $\begin{array}{l}\text { Urban: } 95 \text {. percentile } \\
\mathrm{V} \cdot \mathrm{a}_{\text {pos }}\left[\mathrm{m}^{2} / \mathrm{s}^{3}\right]\end{array}$ & 14.1 & Correct & Correct \\
\hline $\begin{array}{l}\text { Rural: } 95 \text {. percentile } V \cdot a_{\text {pos }} \\
{\left[\mathrm{m}^{2} / \mathrm{s}^{3}\right]}\end{array}$ & 19.5 & Correct & Correct \\
\hline $\begin{array}{l}\text { Highway: } 95 \text {. percentile } \\
\mathrm{V} \cdot \mathrm{a}_{\text {pos }}\left[\mathrm{m}^{2} / \mathrm{s}^{3}\right]\end{array}$ & 15.5 & Correct & Correct \\
\hline Urban: RPA $\left[\mathrm{m} / \mathrm{s}^{2}\right]$ & 0.14 & Correct & Correct \\
\hline Rural: RPA [m/ $\left.\mathrm{s}^{2}\right]$ & 0.08 & Correct & Correct \\
\hline Highway: RPA $\left[\mathrm{m} / \mathrm{s}^{2}\right]$ & 0.04 & Correct & Correct \\
\hline
\end{tabular}

Results of energy consumption tests by the electric passenger vehicle tested on the route set for the purpose of RDE test was presented in Table 6.

Table 6. Energy consumption by an electric passenger car on a route set for the purpose of an RDE test

\begin{tabular}{|l|c|c|c|c|}
\hline Item & Unit & Test 1 & Test 2 & Average \\
\hline $\begin{array}{l}\text { Energy } \\
\text { consumption }\end{array}$ & $\mathrm{kWh} / 100 \mathrm{~km}$ & 18.9 & 20.2 & 19.6 \\
\hline
\end{tabular}

Results of the tests of electrical energy consumption by the electric passenger car tested show that it is from the upper range of energy consumption at $15-20 \mathrm{kWh} / 100 \mathrm{~km}$, an energy use range by typical electric city cars. Assuming the cost of electrical energy consumption at, for example PLN 0.6/kWh, operating costs of such vehicle, at PLN 9-12 per $100 \mathrm{~km}$ are modest. They can be reduced further using night time electricity rates and the cost of electrical energy of PLN $0.3-0.4 / \mathrm{kWh}$ in that case [16]. Larger passenger electric cars use greater amounts of electrical energy (20$25 \mathrm{kWh} / 100 \mathrm{~km}$ ), but electrical energy consumption costs are in their case far lower than fuel consumption costs by passenger cars with conventional engines [16].

Electric cars include cars equipped with fuel cells. At present, the development of hydrogenization of vehicle transportation in a number of countries (e.g. Japan, Germany, Sweden) is very dynamic.

\section{Development of hydrogenization - cars equipped with fuel cells (FCEV)}

Area for practical use of hydrogen as a fuel carrier is transport, including in particular road transport. In recent years 2 motor companies (Hyundai, Toyota) have launched the serial production of fuel cell vehicles (FCEV) and others such as Volkswagen, Mercedes Benz, BMW, General Motors also produce such vehicles. The start of serial production by those companies depends on the availability of expanded hydrogen refuelling network of HRS (Hydrogen Refueling Stations). In 2016 there were only c.a. 200 such stations available in the world. It is expected that by 2020 the number of HRS should come to approx. 1000 and by 2025 - to c.a. 3500 (Table 7).

Table 7. Number of public HRS worldwide in 2016 and their projected number in 2020-2025 [9]

\begin{tabular}{|c|c|c|c|c|}
\hline Year & USA & Europe & Asia & Total \\
\hline 2016 & 60 & 100 & 103 & 263 \\
\hline 2020 & 130 & 520 & 340 & 990 \\
\hline 2025 & 600 & 2000 & 830 & 3430 \\
\hline
\end{tabular}

Source: H2 Mobility, USDOE, Hydrogen Europe, Air Liquid - cited from: How hydrogen empowers the energy transition, Hydrogen Council 2017 , p. 9.

This HRS in 2025 should provide service for approx. 2 million hydrogen vehicles. Currently approx. several thousand vehicles fuelled with hydrogen are used in the world, including more than 1000 in the US and 2000 in Japan and several hundred in Western Europe. A dynamic growth of fleets of hydrogen vehicles is planned - for example China expects to have 50 thousand hydrogen vehicles in 2025, to eventually exceed one million in 2030, whereas Japan will have a fleet of 40 thousand hydrogen vehicles in 2020 and approx. 300 thousand in 2030. According to projections of 2014 - the European fleet of hydrogen vehicles is expected to have 350 thousand vehicles in 2020, the fleet in Japan - 100 thousand, in Korea - 50 thousand and in the US - 20 thousand [9].

Also, the fleet of hydrogen-fuelled buses is to be developed - in Europe it will have 1000 buses in 2020, while for instance in South Korea - almost 30 thousand buses by 2030.

In Poland, there are practically no vehicles equipped with fuel cells (for that reason, at present, it is impossible to obtain a vehicle of this type for energy consumption tests, such research will be conducted at a later date). However, it was developed by Motor Transport Institute "Circumstances of the national plan for hydrogenization of road transport in Poland". In the first place taken into account were [17]:

- already existing refuelling opportunities in the neighboring countries,

- the expected future HRS locations in the Baltic countries,

- gradually increasing the area available for hydrogenpowered cars as a result of the subsequent location of new stations at distances up to $300 \mathrm{~km}$ from the existing or sequentially from the newly-opened ones [17].

With the above criteria, the order of preliminary proposals to build base HRS in Poland are as follows: 1 - Poznan, 2 - Warsaw, 3 - Bialystok, 4 - Szczecin, 5 - Lodz area, 6 - Tri-City area, 7 - Wroclaw, 8 - Katowice region, 9 - Krakow (Fig. 4, Fig. 5) [17]. 


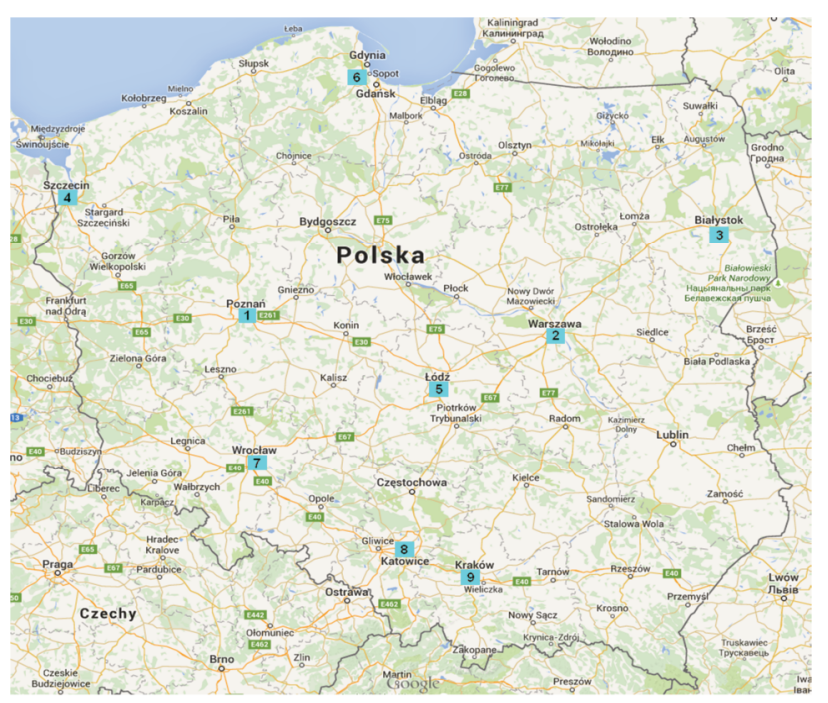

Fig. 4. Map of Poland with marked sites of the proposed public hydrogen refuelling station locations [17]

\section{Summary}

Development of electromobility and hydrogenization of vehicle transport is determined by the development of infrastructure consisting of charging stations for electric vehicles and refuelling stations for cars equipped with fuel cells (HRS). This will generate an increase in the number of vehicles of that type in use. For example, at present in Japan there are 92 HRS stations and approximately 2300 cars equipped with fuel cells are in use.
It will also generate the need to solve a number of technical issues, research related to, for example, determining battery durability or the range of electric vehicles and the associated consumption of electrical energy, which also applies to electric cars equipped with fuel cells. With respect to the latter issue, the article presents a method to evaluate such consumption during an RDE test on a new research route in a real driving condition.

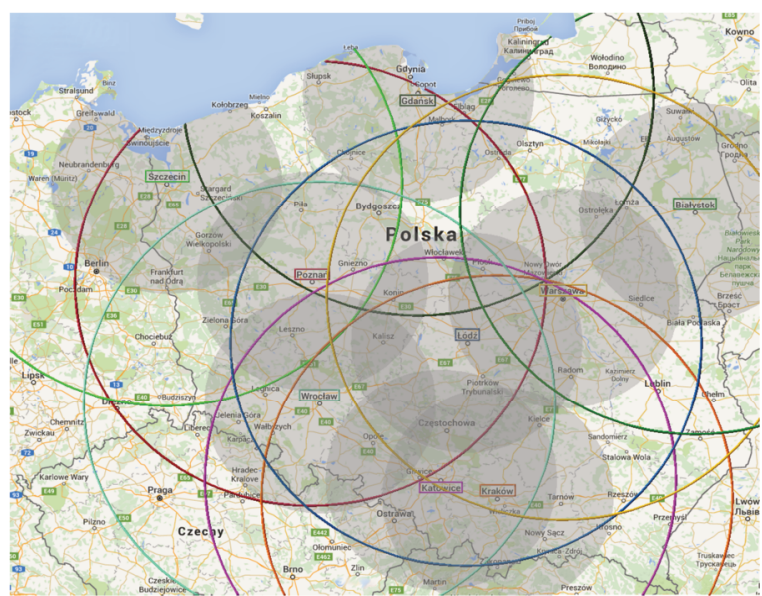

Fig. 5. Penetration area of cars using fuel cells based on 9 hydrogen refuelling stations situated on the national TEN-T road network by the 2030 [3] a) when driving in one direction (diameter of large circles - to approx. 600 $\mathrm{km}$ ), b) when driving there and back (diameter of small, shaded circles - to approx. $300 \mathrm{~km})$ [17]

\section{Nomenclature}

$\begin{array}{llll}\text { BEV } & \text { Battery Electric Vehicle } & \text { NEDC } & \text { New European Driving Cycle } \\ \text { EV } & \text { Electric Vehicle } & \text { RDE } & \text { Real Driving Emissions }\end{array}$

FCEV Fuel cell Electric Vehicle

\section{Bibliography}

[1] COMMISSION REGULATION (EU) 2016/427 of 10 March 2016 amending Regulation (EC) No 692/2008 as regards emissions from light passenger and commercial vehicles (Euro 6)

[2] COMMISSION REGULATION (EU) 2017/1151 of 1 June 2017 supplementing Regulation (EC) No 715/2007 of the European Parliament and of the Council on type-approval of motor vehicles with respect to emissions from light passenger and commercial vehicles (Euro 5 and Euro 6) and on access to vehicle repair and maintenance information, amending Directive 2007/46/EC of the European Parliament and of the Council, Commission Regulation (EC) No 692/2008 and Commission Regulation (EU) No 1230/2012 and repealing Commission Regulation (EC) No 692/2008

[3] COMMISSION REGULATION (EU) 2018/1832 of 5 November 2018 amending Directive 2007/46/EC of the European Parliament and of the Council, Commission Regulation (EC) No 692/2008 and Commission Regulation (EU) 2017/1151 for the purpose of improving the emission type approval tests and procedures for light passenger and commercial vehicles, including those for in-service conformity and real-driving emissions and introducing devices for monitoring the consumption of fuel and electric energy

[4] MERKISZ, J., PIELECHA, J., LIJEWSKI, P. et al. Conference: 21 st International Conference on Modelling, Monitor- ing and Management of Air Pollution. WIT Transactions on Ecology and the Environment. 2013, 174, 27-38.

[5] MERKISZ, J., PIELECHA, J. Comparison of real driving emissions tests. IOP Conf. Ser.: Mater. Sci. Eng. 2018, 421, 042055. DOI: 10.1088/1757-899X/421/4/ 042055

[6] PIELECHA, J., MAGDZIAK, A., BRZEZIŃSKI, L. Nitrogen oxides emission evaluation for Euro 6 category vehicles equipped with combustion engines of different displacement volume. IOP Conf. Ser.: Earth Environ. Sci. 2019, 214, 012010. DOI: $10.1088 / 1755-1315 / 214 / 012010$

[7] PIELECHA, I., CIEŚLIK, W., SZAŁEK, A. Energy recovery potential through regenerative braking for a hybrid electric vehicle in a urban conditions. IOP Conf. Ser.: Earth Environ. Sci. 2019, 214, 012013.

[8] GIS, W., MENES, M. The development of the world electric vehicles fleet in years 2010-2017. KONMOT. 2018.

[9] GIS, W. Electromobility and hydrogenization of the motor transport in Poland now and in the future. Journal of KONES Powertrain and Transport. 2018, 25(4).

[10] GIS, M., BEDNARSKI, M., ORLINSKI, P. Energy analysis of charging infrastructure for electric vehicles on the TEN-T road network. 11th Conference on Interdisciplinary Problems in Environmental Protection and Engineering. EKODOK. Polanica Zdrój, 8-10.04.2019. 
[11] EEA, 2018a Electric Vehicles as the Proportion of the Total Fleet. (https://www.eea.europa.eu/data-and-maps/indicators/ proportion-of-vehicle-fleet meeting-4/assessment-2)

[12] EAFO, 2018, Electric Vehicles Market Share. (https:// www.eea.europa.eu/publications/electric-vehicles-ineurope), Accessed 24 May 2018.

[13] HAMPSHIRE, K., GERMAN, R., PRIDMORE, A., FONS, J. Electric vehicles from life cycle and circular economy perspectives. Version 2, 25 June 2018.

[14] ACEA Registration Figures. http://www.acea.be/statistics/ tag/category/registrations-and-press-release-calendar. Accessed 23 June 2018.

[15] PIELECHA, J. (ed.). Badania emisji zanieczyszczeń silników spalinowych. Wydawnictwo Politechniki Poznańskiej. Poznań 2017.

Wojciech Gis, DSc., DEng. - Prof. ITS, Motor Transport Institute.

e-mail:wojciech.gis@its.waw.pl
[16] http://samochodyelektryczne.org (accessed 11/2018).

[17] GIS, W., MENES, E., WAŚKIEWICZ, J. et al. Circumstances of the national plan or hydrogenization of road transport in Poland. Report prepared as part of the HIT-2Corridors project.

[18] MERKISZ, J., GIS, M. The growth in the use of methane fuel for fuelling urban buses. 10th Conference on Interdisciplinary Problems in Environmental Protection and Engineering (EKO-DOK). Polanica Zdroj, 16-18.04.2018.

[19] GIS, W., PIELECHA, J., WASKIEWICZ, J. et al. Use of certain alternative fuels in road transport in Poland. Scientific Conference on Automotive Vehicles and Combustion Engines (KONMOT). Krakow, 22-23.09.2016.

Prof. Jerzy Merkisz, DSc., DEng. - Faculty of Transport Engineering, Poznan University of Technology.

e-mail: jerzy.merkisz@put.poznan.pl 